\title{
Case 2730
}

\section{Cheilosia Meigen, 1822 and Pyrophaena Schiner, 1860 (Insecta, Diptera): proposed conservation}

\author{
A.V. Barkalov \\ Biological Institute, Siberian Branch of the Academy of Sciences of the \\ U.S.S.R., Novosibirsk 630091, U.S.S.R.
}

\section{I.M. Kerzhner \\ Zoological Institute, Academy of Sciences of the U.S.S.R., St Petersburg 199034, U.S.S.R.}

\begin{abstract}
The purpose of this application is to conserve the names of two genera of hover-flies, Cheilosia Meigen, 1822 and Pyrophaena Schiner, 1860 (family SYRPHIDAE). Both names are threatened by the unused senior name Cheilosia Panzer, [1809], as a homonym and as an objective synonym respectively. It is proposed to fix Syrphus flavipes Panzer, 1798 as the type species of Cheilosia Meigen in accordance with existing usage. Cheilosia Meigen includes approximately 350 species in the Palaearctic, Nearctic and Oriental regions. It is the type genus of the tribe CHEILOSIINI Shannon, 1922. Species included in the genus have economic importance as pollinators, pests of weeds, and as causing damage in the timber of some American coniferous trees. Pyrophaena Schiner, 1860 includes some 10 species, distributed in the Palaearctic and Nearctic regions.
\end{abstract}

1. Panzer ([1809], p. 14, pl. [14]; see Saunders (1888) and Sherborn (1923) for the date of publication) published the new generic name Cheilosia in combination with Syrphus rosarum Fabricius, 1787 (p. 341 ) and illustrated the species. Citation of the specific name makes Cheilosia an available name (Article 12b(5) of the Code), though the absence of a generic description was probably the reason why many subsequent authors neglected the name; rosarum is fixed as the type species by monotypy. The same species is also the type of Pyrophaena Schiner, 1860 (p. 213) by monotypy, and Pyrophaena is therefore a junior objective synonym of Cheilosia Panzer.

2. Meigen (1822, p. 296) noted that 34 species of Syrphus Fabricius, 1775 which he had described on preceding pages formed a distinct group. He described the characters of the group but concluded that they were insufficient to establish a new genus, which he had planned to name Cheilosia, and he therefore retained the species within Syrphus.

An application (Case 2749) which included proposals for the conservation of Cheilosia Meigen, 1822 and Pyrophaena Schiner, 1860, as well as Eristalis Latreille, 1804, Helophilus Fabricius, 1805, Xylota Meigen, 1822 and Eumerus Meigen, 1822, was received from Dr T. Zatwarnicki (Academy of Agriculture, Wroclaw, Poland) shortly after the present one. An application to conserve the last four names is now published (see BZN 48: 308-311). 
The name Cheilosia, first published in synonymy with Syrphus, is an available name (Article 11e), with authorship ascribed to Meigen (Article 50g). Subsequent authors (Lepeletier \& Serville, 1828, p. 512), as well as Meigen himself (1838, pp. 123-129, pl. 68, figs. 1-6), accepted Cheilosia as a distinct genus. Meigen (1838) placed 48 species in the genus. The authorship and concept of Cheilosia, as used in the first half of the 19th century, was variable (see Goffe, 1944, pp. 238-240), but Walker (1851, pp. 280-284), and later Loew (1857) in his revision of the genus, accepted Meigen's (1822) authorship and concept. They have been followed by nearly all subsequent authors in further revisions (Becker, 1894; Hull \& Fluke, 1950), in catalogues (Aldrich, 1905, pp. 351-353; Bezzi \& Stein, 1907, pp. 21-41; Knutson, Thompson \& Vockeroth, 1975, pp. 329-330), and in many hundreds of taxonomic, faunistic and ecological papers. The replacement name Chilosia Agassiz, 1846 (p. 80) (an unjustified emendation of Cheilosia Meigen under Article 33b(iii)) was sometimes used in taxonomic literature until 1956 (Violovitsh, 1956, p. 466) but from 1960 all authors have used the name Cheilosia Meigen.

3. Westwood ([1840], p. 137) designated Musca scripta Linnaeus, 1758 (p. 594) as the type species of Cheilosia Meigen but scripta was not among the originally included species. Rondani (1856, p. 51) designated Eristalis scutellatus Fallén, 1817 (p. 55) (wrongly credited to Fabricius) as the type of Cheilosia (wrongly credited to Megerle); scutellatus was an originally included species and Rondani's designation is valid. Wirth, Sedman \& Weems (1965, p. 583) and Knutson, Thompson \& Vockeroth (1975, p. 329) accepted scutellatus as the type species. However, Meigen (1822, p. 289) noted, under Syrphus flavipes Panzer, 1798 (p. 10, pl. [10]), that he obtained material of this species from Megerle under the name Cheilosia depila (a nomen nudum), and this has led some authors (Coquillett, 1910, p. 521 and Goffe, 1944, p. 239) to record that Cheilosia Meigen was established as a monotypic genus with Syrphus flavipes as the type. Coquillett's (1910) action constitutes a type designation (Article 69a(iv)) but postdates that of Rondani (1856). The species Syrphus rosarum, the type of Cheilosia Panzer, was included in Meigen's (1822) work but was not among the species included in his concept of Cheilosia.

4. Cheilosia Panzer, [1809] and Cheilosia Meigen, 1822 are placed in different subfamilies of SYRPHIDAE, i.e. SYRPHINAE and MILESIINAE respectively. Goffe (1944, pp. 244-245) noted that Cheilosia Panzer was an available name, and used it in place of Pyrophaena Schiner, 1860 (a junior objective synonym). He replaced Cheilosia Meigen (a junior homonym) by Cartosyrphus Bigot, 1883 and Chilomyia Shannon, 1922. With few exceptions (e.g. Kloet \& Hincks, 1945, p. 381) Goffe's changes in nomenclature have not been accepted and both Cheilosia Meigen and Pyrophaena Schiner are in current use (see para. 2). Wirth, Sedman \& Weems (1965, pp. 578, 583) and Peck (1988, p. 75) have previously commented that for stability of nomenclature the Commission should be asked to suppress Cheilosia Panzer.

5. The current usage of subgeneric names within Cheilosia was established by authors (see, for example, Hull \& Fluke, 1950) who considered Syrphus flavipes Panzer to be the type species (see para. 3). The two principal subgenera are Cheilosia (with hairy eyes) and Cartosyrphus Bigot, 1883 (with naked eyes). Subgeneric names in Cheilosia are widely used by American authors, although rarely in Europe and Asia. Eristalis scutellatus Fallen, the type species of Cheilosia Meigen by Rondani's (1856) designation, is a species with naked eyes, although it was included by Meigen (1838, 
p. 123), probably due to an error or the misidentification of some specimens, in his species-group 'A' (with hairy eyes). Recognition of scutellatus as the type species would mean that the subgenus Cartosyrphus would be renamed Cheilosia and the subgenus currently named Cheilosia would need another name. Such changes in nomenclature are destabilising and we therefore propose the fixation of Syrphus flavipes Panzer, 1798 as the type species.

6. The International Commission on Zoological Nomenclature is accordingly asked:

(1) to use its plenary powers:

(a) to suppress the generic name Cheilosia Panzer, [1809], and all uses of the name Cheilosia prior to the publication of Cheilosia Meigen, 1822, for the purposes of both the Principle of Priority and the Principle of Homonymy;

(b) to set aside all designations of type species for the nominal genus Cheilosia Meigen, 1822 prior to that by Coquillett (1910) of Syrphus flavipes Panzer, 1798;

(2) to place on the Official List of Generic Names in Zoology the following names:

(a) Cheilosia Meigen, 1822 (gender: feminine), type species by subsequent designation by Coquillett (1910), Syrphus flavipes Panzer, 1798, as ruled in (1)(b) above;

(b) Pyrophaena Schiner, 1860 (gender: feminine), type species by monotypy Syrphus rosarum Fabricius, 1787;

(3) to place on the Official List of Specific Names in Zoology the following names:

(a) flavipes Panzer, 1798, as published in the binomen Syrphus flavipes (specific name of the type species of Cheilosia Meigen, 1822);

(b) rosarum Fabricius, 1787, as published in the binomen Syrphus rosarum (specific name of the type species of Pyrophaena Schiner, 1860);

(4) to place on the Official Index of Rejected and Invalid Generic Names in Zoology the following names:

(a) Cheilosia Panzer, [1809], as suppressed in (1)(a) above;

(b) Chilosia Agassiz, 1846 (an unjustified emendation of Cheilosia Meigen, 1822).

\section{References}

Agassiz, L. 1846. Nomenclatoris Zoologici Index Universalis. viii, 393 pp. Soloduri.

Aldrich, J.M. 1905. A catalogue of North American Diptera. Smithsonian Miscellaneous Collections, 46(1444): 1-680.

Becker, T. 1894. Revision der Gattung Chilosia Meigen. Nova Acta Academiae Caesareae Leopoldino-Carolinae Germanicae Naturae Curiosorum, 62(3): 195-521.

Bezzi, M. \& Stein, P. 1907. Katalog der paläarktischen Dipteren, vol. 3.828 pp. Budapest.

Coquillett, D.W. 1910. The type-species of the North American genera of Diptera. Proceedings of the United States National Museum, 37: 499-647.

Fabricius, J.C. 1787. Mantissa insectorum sistens eorum species nuper detectas adiectis characteribus genericis, differentiis specificis, emendationibus, observationibus, vol. $2.382 \mathrm{pp}$. Hafniae.

Fallén, C.F. 1817. Diptera Sveciae... Dipterorum antennis parum articulatis instructorum sectionem... continens, vol. 1. Syrphici Sveciae. 62 pp. Lundae.

Goffe, E.R. 1944. The genera Cheilosia (Chilosia) Panzer, 1809; Meigen, 1822; Hoffmannsegg: Chilomyia Shannon: Cartosyrphus Bigot (Dipt., Syrphidae). The Entomologist's Monthly Magazine, (4)80(58, 59): 238-248. 
Hull, F.M. \& Fluke, C.L. 1950. The genus Cheilosia Meigen (Diptera, Syrphidae). The subgenera Cheilosia and Hiatomyia. Bulletin of the American Museum of Natural History, 94(6): 299- 402 .

Kloet, G.S. \& Hincks, W.D. 1945. A checklist of British insects. lix, 477 pp. Published by the authors, Stockport.

Knutson, L.V., Thompson, F.C. \& Vockeroth, J.R. 1975. Family Syrphidae. Pp. 307-374 in Delfinado, M.D. \& Hardy, D.E. (Eds.), A catalog of the Diptera of the Oriental region, vol. 2. 459 pp. University Press of Hawaii, Honolulu.

Lepeletier de St Fargeau, A.L.M. \& Serville, J.G.A. 1828. Syrphe, Syrphus. Pp. 511-526 in: Encyclopédie Méthodique, vol. 10, part 2. Pp. 345-832. Agasse, Paris.

Linnaeus, C. 1758. Systema Naturae, Ed. 10, vol. 1.824 pp. Salvii, Holmiae.

Loew, H. 1857. Die europäischen Arten der Gattung Cheilosia. Verhandlungen der ZoologischBotanischen Gesellschaft in Wien, 7: 579-616.

Meigen, J.W. 1822, 1838. Systematische Beschreibung der bekannten europäischen zweiflügeligen Insekten, vol. 3, x, 416 pp. (1822); vol. 7, xii, 434 pp. (1838). Hamm.

Panzer, G.W.F. 1798, [1809]. Faunae insectorum germanicae initia oder Deutschlands Insecten, Heft 54, 24 pp., 24 pls (1798); Heft 108, 24 pp., 24 pls. ([1809]). Nürnberg.

Peck, L.V. 1988. Family Syrphidae. Pp. 11-230 in Soós, A. \& Papp, L. (Eds.), Catalogue of Palaearctic Diptera, vol. 8. 363 pp. Elsevier, Amsterdam.

Rondani, C. 1856. Dipterologiae Italicae prodromus, vol. 1 (Genera Italica ordinis Dipterorum...). 265 pp. Parma.

Saunders, E. 1888. Index to Panzer's 'Fauna Insectorum Germanicae'. 48 pp. Gurney \& Jackson, London.

Schiner, J.R. 1860. Vorläufiger Commentar zum dipterologischen Theile der 'Fauna Austriaca', 2. Wiener Entomologische Monatschrift, 4: 208-216.

Sherborn, C.D. 1923. On the dates of G.W.F. Panzer's 'Fauna Insect. German.', 1792-1844. Annals and Magazine of Natural History, (9)11(64): 566-567.

Violovitsh, N.A. 1956. Neue Syrphiden (Diptera, Syrphidae) aus Sachalin-Gebiet. Entomologicheskoe Obozrenie, 35(2): 462-472.

Westwood, J.O. [1840]. Synopsis of the genera of British insects, pp. 97-154. Published with An introduction to the modern classification of insects..., vol. 2, part 16, pp. 401-587. Longman, Orme, Brown, Green \& Longmans, London.

Walker, F. 1851. Insecta Britannica, Diptera, vol. 1. 313 pp. Reeve \& Benham, London.

Wirth, W.W., Sedman, Y.S. \& Weems, H.V. 1965. Family Syrphidae. Pp. 557-625 in Stone, A., Sabrosky, C.W., Wirth, W.W., Foote, R.H. \& Coulson, J.R. (Eds.), A catalog of the Diptera of America north of Mexico. Agricultural Handbook No. 276. iv, 1696 pp. United States Department of Agriculture, Washington. 


\section{$2 \mathrm{BHL}$ Biodiversity Heritage Library}

Barkalov, Anatolij Vasilievich and Kerzhner, Izyaslav M. 1991. "Cheilosia Meigen, 1822 and Pyrophaena Schiner, 1860 (Insecta, Diptera): proposed conservation." The Bulletin of zoological nomenclature 48, 312-315. https://doi.org/10.5962/bhl.part.762.

View This Item Online: https://www.biodiversitylibrary.org/item/44489

DOI: https://doi.org/10.5962/bhl.part.762

Permalink: https://www.biodiversitylibrary.org/partpdf/762

\section{Holding Institution}

Natural History Museum Library, London

\section{Sponsored by}

Natural History Museum Library, London

\section{Copyright \& Reuse}

Copyright Status: In copyright. Digitized with the permission of the rights holder.

License: http://creativecommons.org/licenses/by-nc-sa/3.0/

Rights: https://biodiversitylibrary.org/permissions

This document was created from content at the Biodiversity Heritage Library, the world's largest open access digital library for biodiversity literature and archives. Visit BHL at https://www.biodiversitylibrary.org. 